\title{
REFLECTIONS IN THE SETTLEMENT PATTERN AND LANDSCAPE OF SOVIET MILITARY ACTIVITIES IN ZVĀRDE PARISH (LATVIA)
}

Ineta Grine ${ }^{1}$, Dr.geogr., Docent; Ivars Strautnieks², Dr.geol., Assoc.Professor

1,2 University of Latvia, Faculty of Geography and Earth Sciences

\begin{abstract}
A landscape develops through the interaction of natural factors and human economic activities, and accordingly is influenced by changes in the economic, political and social spheres. The article examines changes in settlement in Zvārde Parish during the 20th century and the reflection in the landscape of the activities of the USSR's armed forces and the military legacy. Zvārde Parish was the location of one of the Soviet armed forces' largest military training grounds in Latvia: a former bombing range. This rural area was relatively densely populated in the early 20th century, with a landscape dominated by managed farmland surrounding individual farmsteads, separated by clumps of forest, roads and lakes. Along with the establishment of the military range, the residents were forced to abandon their homes, and the military exercises lasting several decades completely interrupted farming as well as all other peacetime economic activities. Forest developed in the abandoned areas, along with meadows and fields overgrown with scrub. Nowadays, agricultural land has been established only in limited areas. A significant part of the former bombing range is nowadays taken up by protected natural areas. At the present day the parish is sparsely populated, except for its north-western part, which was located outside of the range. The half-collapsed military facilities preserve visual evidence of the former training ground.
\end{abstract}

Key words: military heritage, landscape change, population centres, Zvārde, parish, Latvia.

JEL code: N131

\section{Introduction}

A landscape develops and changes over time through the interaction of natural factors and human economic activities. The natural conditions constitute the basis, determining and influencing the visual image of the landscape, the settlement pattern and the spatial division of different forms of land use. Changes in the economic, political and social sphere also have an effect on the landscape. In Latvia, in the 20th century such critical developments (Melluma, 2010; Melluma, 2012) impacting on the landscape include the destruction of the First and Second World War; the Soviet period with the establishment of collective farms, extensive land improvement work, elimination of individual farmsteads and the formation of villages; and the land reform and advent of the real estate market at the end of the 20th century (Melluma, 2010; Grīne, 2009; Grīne et.al, unpublished). Changes in land use affect the visual value of the landscape (Bell et al., 2010; Nikodemus et al., 2005). The settlement pattern also has an important role in the changes occurring in the landscape and land use (Roca et al., 2011).

In the Soviet period, present-day Latvia had over 500 military sites (Upmalis et al., 2006; Military heritage). The establishment and functioning of these military sites affected the settlement structure and environment and, being a non-traditional form of land use, also had an effect on the landscape as a whole. Following the withdrawal of the Soviet forces, Latvia has been left with a military legacy that has a range of functions - some of the former military sites are utilised by Latvia's National Armed Forces, while others form part of Natura 2000 protected natural sites (Grīne et.al, unpublished). Although the former military sites are now mostly owned by the municipalities, many are abandoned, unmanaged and freely accessible. Some have been included in tourist routes, witnesses to the history of the socialist period, while some may be dangerous because of contamination with ordnance (Military heritage). 
The aim of the study is to assess the changes in settlement pattern and landscape since 1950 in Zvārde Parish, the location in the years 1953-1993 of one of the USSR's largest military areas in Latvia - an aviation bombing range.

\section{Materials and methods}

The study is based on analysis of cartographic material, statistical data and archive material along with the results of fieldwork and internet resources (publications). The main information sources are topographic maps (scale 1:75000, 1:50 000 and 1:25000), satellite maps (scale $1: 50000$ and 1:25 000) and orthophotographs, providing information about the area in the 20th century and about the present-day situation, as well as the Corine Land Cover 2006 and 2012 data. Information about the parish before establishment of the range comes from documents in the State Archive of Latvia and the Museum of the Occupation. It needs to be borne in mind that the statistical data for the 1930s and the Soviet period relate to the area within the administrative boundaries of Zvārde Parish as they were at that time; even so, they help to provide a picture of the area (Grine et.al, unpublished). In the course of the study, fieldwork was conducted in 2011, 2012 and 2015-2017, involving photographic recording and a survey of the residents in 2015 that included 63 people (one individual from each household). Spatial analysis was conducted and new maps created using the GIS software ArcView 10.

\section{Main research results Characterisation of Zvārde Parish.}

Zvārde Parish is located in the southern part of western Latvia, in Saldus Municipality, about $10 \mathrm{~km}$ from Saldus. The former Zvārde aviation bombing range (area: $24418.5 \mathrm{ha}$ ) (The Zvarde base; LR MP lēmums) occupies about $89 \%$ of the area of the parish, and about $75 \%$ of the bombing range lies within Zvārde Parish. The bombing range and the parish as a whole span two divergent areas that differ in terms of relief and height above sea level: the hilly Eastern Kursa Upland and the flat Central Latvia Lowland (Fig. 1A). The relief and geological structure are significant natural factors behind differences in the natural landscape and land use between the lowland and the upland area. The differences in the degree of relief dissection give rise to different drainage and growing conditions. The dominant soil parent material, namely carbonaceous glacial till, is a significant factor, ensuring soil fertility in well-drained areas.

According to statistical data, Zvārde Parish had a population of 334 in 2017 and a population density only 1.6 inhabitants per $\mathrm{km}^{2}$. The population is concentrated mainly in the north-western part of the parish, outside the limits of the former bombing range. Based on data from the catalogue of addresses, in 2017 the parish had 124 populated locations (farmsteads) and a single village - the parish centre at Striki, home to about $20 \%$ of the parish population. According to planning documents, Striki and Zvejnieki have been given the status of villages (Saldus novada teritorijas ..., 2012-2013).

According to data from the population survey (2015), about $47 \%$ are 1-2 person households, and $40 \%$ are 3-4 person households. The survey data indicate that $32 \%$ of respondents have lived in the parish since birth, $52 \%$ have lived here for more than 20 years, and $16 \%$ for less than 20 years. Respondents who have moved to the parish mention the following as the main reasons: factors relating to the family or work, the purchase of a landholding, or better living conditions. The three main factors indicated by respondents as motivating them to stay in the parish are: property ownership, peace and quiet in the countryside, and the family (Grīne, Beneža, 2016). 
A

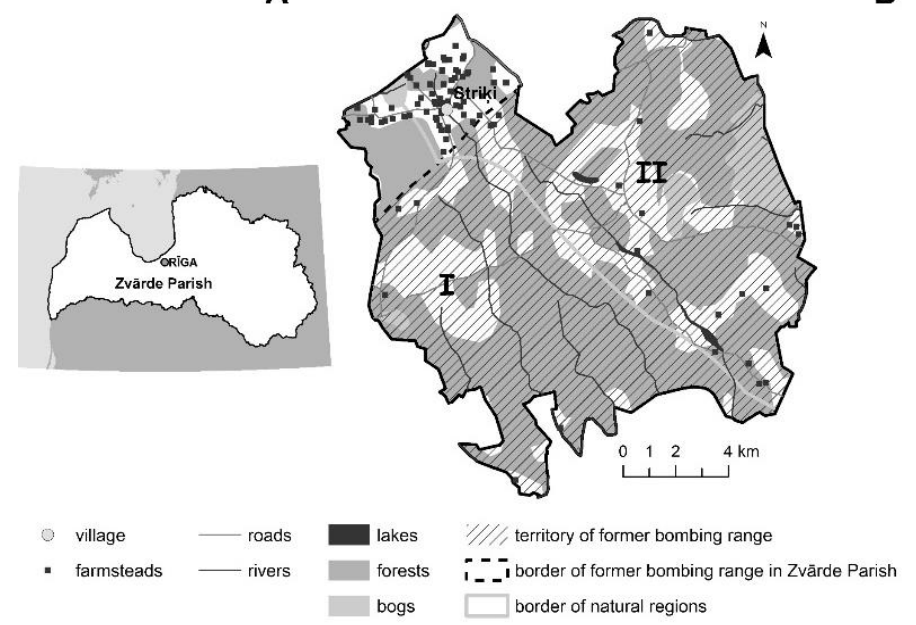

B

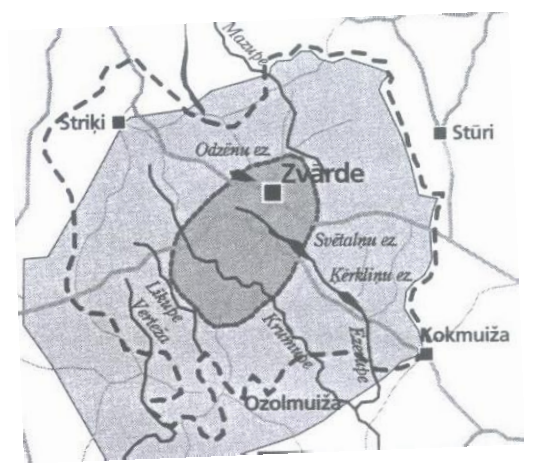

Legend: I - Central Latvia Lowland; II - Eastern Kursa Upland. Hatched area: the former extent of the bombing range. light grey - area of the range; dark grey - active bombing zone

Source: A. author's calculations based on Envirotech Latvija 10.2 gdb; B. after Štāls, 1996

Fig. 1. A. Location of the study area and Zvārde Parish. B. Scheme of Zvārde bombing range (after Štāls, 1996).

\section{Characterisation of the parish during the time of use of the bombing range}

The decision to create an aviation bombing range was taken in 1953, and resulted in the 15th Air Army obtaining use of an area of more than 24 thousand ha (Sprūde, 2011; LR MP lēmums Nr. 329) (Fig. 1B). The territory of the bombing range became a zone closed to the civilian population. Two collective farms established in the 1940s were abolished. As a result, Zvārde Parish was divided into two areas with radically different functions: 1) the area outside the bombing range and 2 ) the area within the range.

The north-western part of Zvārde Parish is a small area that was inhabited during the Soviet period. The largest population centres were Striki, which was the centre of a collective farm (with 157 inhabitants according to statistical data from 1989), as well as Zvejnieki (population in 1989: 52) and Liepas (population in 1989: 34). In terms of buildings and economic activity, the situation was similar to that of other rural areas of Latvia. The landscape includes the historic buildings of Striki Manor as well as an apartment house from the Soviet period at Striki and Livānitype houses at Striki, Zvejnieki and Liepas. A characteristic feature from the Soviet period is the presence of large farms in the environs of the major population centres, where economic activities were concentrated.

The area of the parish that fell within the bombing range developed according to a different scenario. The roads were closed, and the inhabitants had to leave their homes, being resettled in adjacent parishes. During the time the range was in use only a small number of farmsteads continued to exist, mainly at the edge of the range, in its south-eastern part. Several historical cemeteries were destroyed during the time of existence of the range, the largest of these being the Rìteli cemetery (Upmalis et al., 2006).

In order to conceal the military activities, the area was marked on maps from the Soviet period not as a bombing range but as a forest district with a non-Latvian name that is completely out of place in western Latvia, namely the "Morozov Forest District".

During the time when the Zvārde military range was active, it can be divided approximately into three zones. 
1) The active bombing or target zone, which took up about 1.8 thousand ha in the central part of the range. All economic activities in this zone were discontinued, with the exception of ploughing, which made it easier for the airmen to identify their targets (Beneža, 2015). The populated locations and the elements of the cultural landscape that had been preserved up to that time were destroyed. Riteli cemetery became a target area for air strikes. Although the bomb craters were filled and levelled every year, within the active bombing zone the farmland was turned into terrain filled with bomb craters, earthworks and mock military facilities that served as bombing targets. As noted in other publications, targets included farms, churches, cemeteries, roads and other elements of the infrastructure. Bombs and rockets often landed in adjacent areas as well, within a radius of $5-10 \mathrm{~km}$ from the centre of the bombing zone (Grīne et.al, unpublished).

2) Adjacent to the active bombing area was a zone where new military facilities were built and where the historical buildings were placed in the service of the military (Lāce, 2017), thus introducing new features into the landscape. A military unit stationed at the historical population centre of Lapsas had the task of setting up targets and directing bombing runs within the range, and ensuring that civilians did not enter the range. At Zvārde Manor a three-storey building was erected on an artificial mound, used to direct the air force training exercises. Radar facilities were set up on an artificial hill nearby. For the needs of the military, buildings were also erected at Lake Odzēni (Grīne et.al, unpublished).

3) The zone of limited economic activity: here the military undertook forestry work and created a gravel quarry. Grazing of animals and hay-mowing were permitted in small areas at the margin of the bombing range, mainly in the south-eastern and eastern parts of the range. Apart from this, hay-mowing was necessary to maintain the bombing range, preventing the growth of long grass that would ignite from the bombing and cause wildfires (Beneza, 2015). Because of this, the area did not become overgrown with scrub and forest: albeit at a limited scale, the land was managed. Since there were essentially no checkpoints on the small roads in the south-eastern part of the range, civilian residents as well as soldiers would illicitly gather cranberries in the Zvārde and Stūri bogs. Soviet officers would use the visually attractive landscape of meadows and forests around Lake Kerklini as a recreational area (Grine et.al, unpublished).

As indicated by the cartographic material, in 1970-1980 forest cover in the area of the bombing range reached about $75 \%$, with agricultural land taking up about $13 \%$. This is confirmed by the recollections of local residents: "In 1972 ... all the land was overgrown with impenetrable forest. Only the locations of the farms were marked by scraggy lilac shrubs and withered apple trees" (Upmalis et al., 2006).

Zvārde bombing range was closed in 1993 (Tooma, 2004). According to the statistical data, in 1994 the parish had a population of 386 , or 1.9 inhabitants per $\mathrm{km}^{2}$. Since the closure of the range, Zvārde Parish has been a sparsely populated area. The population of the parish is eight times lower today than it was in 1935.

Even today, differences in the settlement pattern remain between the former area of the bombing range and the north-western part of the parish, outside the range. Thus, farms and villages are mainly concentrated in the north-western part of Zvārde Parish. In the former area of the range, there are no more than 20 farms, most of them in the south-eastern part (Fig. 3), in areas with a visually attractive landscape. 
The land use pattern is closely related to the divergent settlement pattern. Outside the area of the range there is a landscape of unbroken farmland surrounding the population centres, namely Striki, Zvejnieki and Liepas, whereas the western part has extensive tracts of forest.

The former bombing range presents a mosaic landscape consisting of forest and clumps of trees, alternating with abandoned farmland overgrown with scrub. Most of the area of the former range is occupied by forest, primarily deciduous and coniferous/small-leaved. There are small patches of coniferous forest in a boggy area in the eastern part of the range and to the south of the bogs. Most of the farmland is overgrown with forest and scrub. Farmland constitutes separate "islands" in the south-eastern part of the range: around Lake Kerklini and Jaunzvārde, where limited economic activity was permitted during the time of the bombing range, as well as in the central part of the range (around Rītelji, Veczvārde and Vītinceplis) and in the western part (around Sāti and Lapsas) (Fig. 2). In the central part of the range, there are subglacial lakes surrounded by trees and scrub. Only in places have farmsteads been re-established, with farmland around them. The ruins of churches, former manor buildings and farms constitute landscape elements here and there, hidden in the scrub and trees. The roadways divide the area into separate sections; these are the main routes along which people traverse the terrain, and they provide the immediate visual impression of the parish landscapes. Because of the extensive forest and scrub, the mosaic landscape with newly-established farms is not visible, and the natural as well as artificial features remain concealed. Thus, for example, the main thoroughfares do not provide a view of the scenic hilly landscapes and the deep depressions, within which Lakes Kerklini and Svētaini lie.

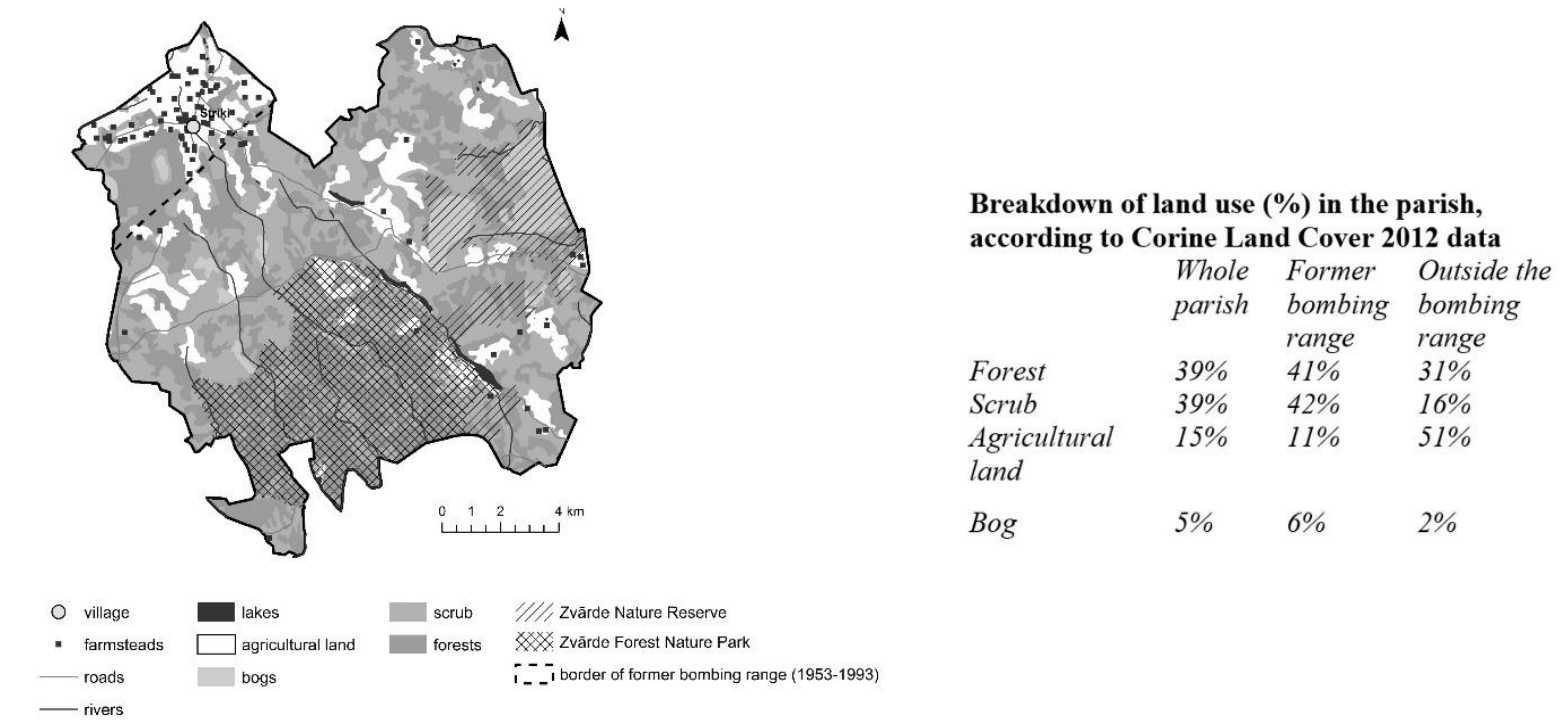

Source: author's calculations based on map 1:50000 scale satellite map and Corine Land Cover 2012

Fig. 2. Zvārde Parish in the 2000s

In order to maintain biodiversity, the Zvārde Nature Reserve was set up in the eastern part of the former range in 1999, encompassing tracts of bog and forest as well as Lake Kerklini and its environs. In 2004, the Zvārde Forest Nature Park was established in the southern part of the former range. Both protected natural areas are included in the Natura 2000 network of protected areas of the EU and are important for migratory birds and as a habitat for rare and protected birds. 


\section{Discussion}

\section{The parish before establishment of the bombing range}

The main factors affecting the landscape and population structure in Zvārde Parish after 1950 are: establishment and use of the aviation bombing range during the Soviet period, as well as closure of the range and land reform following the restoration of Latvia's independence.

In order to better understand the changes occurring since 1950, it is necessary to consider the situation in the area before the bombing range was established. In the 1930s, Zvārde Parish was more densely populated than today (Fig. 3). The parish had 503 populated places in 1935, with 3117 inhabitants (census and statistical data), the population density reaching 15.3 inhabitants per km². The major population centres were Zvārde, Striki and Kerklini. In 1940, Zvārde Parish had about 510 populated locations, of which more than 80 "old farms" are mentioned in church registers starting from 1708 (material in Lapsas Museum; Lāce, 2017).

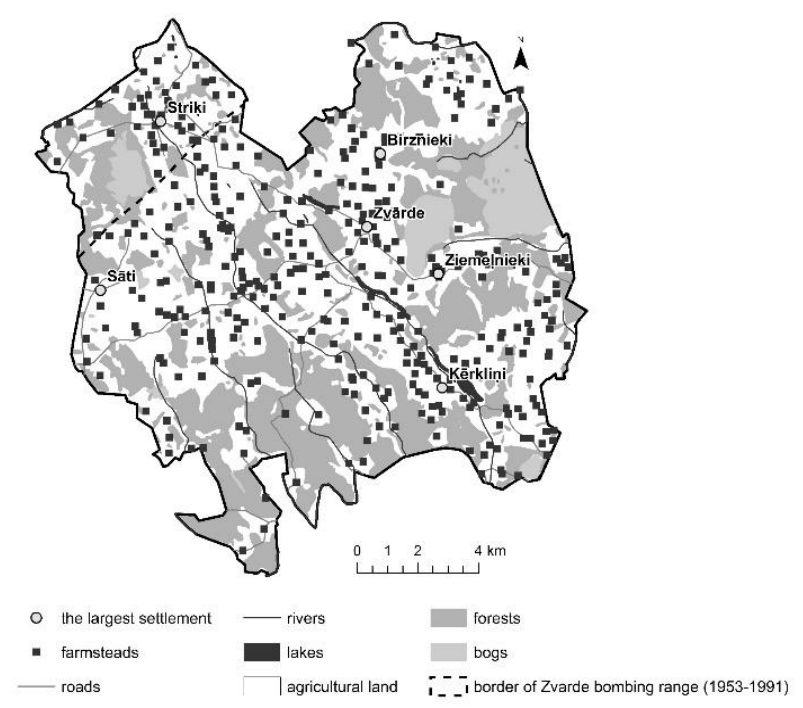

Source: author's calculations based on map 1:75000 scale topographic map

Fig. 3. Zvārde Parish in the 1920s

The mosaic landscape consisted of individual farms, groups of farms and manors, areas of forest and clumps of trees, tracts of bog, lakes and roads. Populated locations were dispersed throughout the area - along the watercourses and major roads, and in the vicinity of the lakes (Fig. 3).

In the early 20th century, more than $60 \%$ of the area of the parish was taken up by agricultural land (within the present administrative boundaries; within this area, the territory of the later bombing range had about $58 \%$ agricultural land) (Fig. 4). Soil fertility provided one of the preconditions for Zvarde's position in the 1930 s as one of the most agriculturally developed parishes of Kuldigga County. As recalled by local residents, "Up to the outbreak of the Second World War, the parish had a large number of wealthy farms, substantial houses and well-tended fields" (Jermaks, 2012; Grīne et al., unpublished).

About $36 \%$ of the total area of Zvārde Parish was covered by forest. The largest tracts of forest were in the south-western part of the area as well as in the eastern part, surrounding the bogs. The main sources of income in Zvārde Parish in the time of independent Latvia were connected with agricultural production: stock-keeping and cereal farming.

During the Second World War, the fighting of 1944-1945 destroyed about $90 \%$ of the buildings, including farms and historical buildings. The ruined houses had to be rebuilt, either 
repaired or built anew (Lāce, 2017). Only in the north-western part around Strīki were farms and outbuildings preserved, and here large farms were subsequently established in the period of collective farming (Lāce, 2017); this area was later excluded from the bombing range. According to statistical data from, Zvārde Parish had a population of 1.7 thousand in 1946, which fell to 1.5 thousand in 1949, in the wake of the deportations (archive sources).

From the outbreak of the Second World War up to the present day the proportions of the different components making up the land use and landscape mosaic have changed markedly.

It is important to consider such facts as the reduction of the area of agricultural land within the area of the range from about $58 \%$ before establishment of the range to only about $11 \%$. The area of agricultural land has fallen more than five times, whereas the extent of forest has increased from $36 \%$ to about $59 \%$ in 2006 (41\% in 2012). This pronounced reduction in agricultural land in an area of fertile soils is in itself a pointer to major historical developments. Changes in the parish are indicated not only by statistical data but also by cartographic material and photographs, which permit comparison of the landscapes before the Second World War with those of the present day. In the 1930s, the landscape included many farms and manors with occasional clumps of forest and trees, whereas nowadays the landscape is constituted mainly of forest tracts and scrub, surrounding lakes, bogs, roads and the ruins of historic cultural sites. The presence of the former farms, landholdings and historical sites is indicated only by ruins overgrown with scrub and trees, along with lilac and apple trees, as well as the farm names appearing on old maps, and information stands and historical photographs. After the Second World War, agricultural land could have been taken back into use, but this was interrupted by the establishment of the Zvārde aviation bombing range during the Soviet period. In contrast to the rest of the parish territory, farmland within the range could not be utilised for at least 40 years (during the life of several generations). This is sufficient time for the former arable land to change into forest, and for meadows to become overgrown with scrub. Witnesses to the former bombing range include half-collapsed military facilities, such as the mound with the ruins of the observation tower. Also testifying to the functioning of the bombing range is the overgrown meadow with bomb craters and a few crosses next to Riteli cemetery. The military heritage at Lapsas is in use today: there is a shooting-range (SIA Zvārdes šautuve), a museum room has been created in the former barracks, and other buildings have been adapted for economic purposes - as a sawmill (Grīne et.al, unpublished).

In the hilly terrain of the parish as a whole the open landscape with agricultural land and farms has been replaced in the 20th century by a mainly closed landscape of forest, scrub and overgrown meadows. Only some of the hilltops provide a wide, clear view of the surroundings - for example, the artificial mound, where scrub is gradually reducing the panoramic view. Those areas of the landscape not being managed or cultivated are becoming overgrown. There is a landscape of farmland only in the northern part of the hilly area - where economic activity also occurred in the Soviet period.

Within the hilly area a lake landscape and a bog landscape may be distinguished, these having a major role in biological and landscape diversity. The lake landscape is formed by subglacial lakes: the Lakes Kerklini, Svētaini and Odzēni and the environs, with forest and small areas of farmland. Cartographic material shows that in the 1920s and 1930s all three lakes were clearly visible from the Kokmuiža-Striki road, whereas today there are wide belts of vegetation along the lakes, with forest and scrub, and access to the lakes is limited because of private land ownership. Farmsteads have been re-established along the Lake Kerklini, and farmland has been created around them; the 
lake landscape is gradually being managed, reducing the area of scrub. However, the managed lake landscape can be reached only by a very limited number of people, because the private land is not accessible to tourists. The bog landscape has seen little change: here, natural processes occur more slowly and human impact is not significant.

In the flat landscape of the Central Latvia Lowlands, roads play a significant role, constituting boundary areas between separate blocks of the landscape. In the early 20th century, most of the area consisted of a mosaic landscape dominated by agricultural land, whereas now in the southern part of the plain the landscape is formed by forest tracts, with small bogs in places. The farmland, left uncultivated for 60 years, has become overgrown with forest and scrub. Agricultural land now forms small "islands" within tracts of forest.

Whereas the establishment of the bombing range, along with the elimination of settlement and economic activities, was instituted by means of a single decision, the re-establishment of settlement and economic activity after closure of the range has been a gradual process. The former owners regained their lands in the course of the land reform of the 1990s. About 350 former owners and their heirs wished to regain their properties, and about 130 requested compensation (Virbicka, 1993). Many homes had been destroyed in the war and during the time the range was in use. Houses had to be built anew, which required financial means as well as equipment and a great deal of work. Because of a shortage of funds and equipment, only a small proportion of the former farms have been re-established, rebuilding the houses and taking up farming again (Štāls, 1996; Jermaks, 2012; Grīne et.al, unpublished).

The lack of roads also affected the resumption of economic activities. Saldus-Striki-Kokmuiža road was re-established only in the mid-1990s thus providing partial access to this area. Other roads have been built by forest owners in order to facilitate forest management. Power lines have also had to be re-established.

According to visits in the field and data from the survey of residents (2015), agriculture is mainly being practiced today in the area that remained outside the bombing range. There are only a small number of large farms, and their owners are leasing land in order to augment their farming activities. The landowners are mainly engaged in farming, forestry and beekeeping, with dairy and sheep farming on some holdings. Respondents also named cereal farming, stock farming and beekeeping as branches of agriculture with potential for development in the parish. These results confirm the idea expressed in other studies that the farmers themselves connect the development of rural areas with the development of farming (Latvijas lauku telpas ..., 2012). Survey data indicate that agricultural land is mainly being managed in order to maintain a tended landscape $(40 \%)$, provide for the family $(25 \%)$ and receive EU direct payments $(17 \%)$. EU agricultural policy directly or indirectly influences land use and the development of the rural landscape (Bell et al., 2010; Penēze, 2009), along with the maintenance of landscapes. EU payments promote the maintenance of agricultural land, but do not always promote agricultural activity (Ruskule, 2013; Vanwambeke et al., 2012). Apart from this, $25 \%$ of respondents indicate that they are not engaged in agriculture.

Agriculture and forestry are also hampered by soil contamination with fine metal splinters and unexploded ordnance in the active bombing zone as well as outside it. The bombing range has still not been completely cleared of unexploded bombs. Even in 2011-2015, unexploded Soviet ammunition as well as shells from the Second World War were discovered. This contamination extended within a total area of about 12 thousand ha (Drike, 2001; Svetoka, 2012; Ozola, 2015). 
This means that the area is contaminated and dangerous for local residents and tourists alike, and it is the reason why agricultural land remains uncultivated in many areas.

Economic activities within the former bombing range are also limited because of the establishment of the Zvārde Forest Nature Park and the Zvārde Nature Reserve, intended to preserve the undisturbed natural assets and biodiversity. It is the beautiful scenery, the attractive hilly landscape with lakes and the historical heritage that provide significant potential for the development of tourism.

\section{Conclusions}

1) Visual evidence of the period before establishment of the bombing range and the time it was in use as well as cartographic information indicate that the main influence on landscape changes has been the Zvārde range, which interrupted normal life and economic activity for more than 40 years.

2) The reduction in populated places and the interruption of economic activities has brought about an increase in areas overgrown with forest and scrub at the expense of former agricultural land. Open landscapes with farmland and farms have generally been replaced with closed forest landscapes and scrub.

3) Nowadays, economic activities - both agriculture and forestry - can be undertaken throughout the area of the range, except for the former bombing zone and the nature reserve and nature park, where economic activities are still restricted today.

4) The territory with lakes and adjacent forest tracts and open areas, including farmland, constitutes a mosaic hilly landscape, one of the most attractive in the Eastern Kursa Upland, offering a significant resource for tourism and recreation.

5) The extensive overgrown belts around the lakes as well as the restricted access to them because of private land ownership hinder the development of tourism and the public environmental education. The area has an insufficient tourist infrastructure.

The former Zvārde bombing range is regarded as a unique legacy of military activity, with important cultural history sites. The historical churches and manors, and the devastated Riteli cemetery testify to the attitude of an alien power and ideology towards the local population and their culture. The cemeteries overgrown with scrub and forest within the area of the Zvārde range are also a consequence of military activity, whereas vandalism in the cemetery of Sili, which took place after closure of the range, is not due to the Russian military. The cultural and natural sites in Zvārde Parish, along with the experience that has been built up and the information brought together concerning the parish are significant for public education, tourism, the economy and the country's future development.

\section{Bibliography}

1. Bells, S., Nikodemus, O. (2000). Meža ainavas plānošanai un dizainam. Rokasgrāmata (Forest landscapes for planning and design. Handbook). Rīga: Valsts Meža dienests, $76 \mathrm{p}$.

2. Bell, S., Alves, S., de Oliveira, E., Zuin, A. (2010). Migration and land use change in Europe: a Review. Retrieved: http://landscaperesearch.livingreviews.org/Articles/Irlr-2010-2/download/Irlr-2010-2Color.pdf. Access: 29.01.2018.

3. Beneža, S. (2015). Apdzīvojuma struktūras un zemes lietojumveidu izmainas Zvārdes pagastā (20.gs. sāk. - 21.gs. sāk) (Changes of settlement structure and landuse in Zvarde Parish (beginning of the 20th century - beginning of the 21st century). Rīga: LU, 73 p.

4. Dabas parka "Zvārdes meži” dabas aizsardzības plāns (Nature Park "Zvardes forests' conservation plan) (2005). Retrieved: https://www.daba.gov.Iv/upload/File/DAPi_apstiprin/DP_Zvardes_mezi-05.pdf. Access: 29.01.2018. 
5. Drike, I. (2001). Neticami piesārnotā zeme (Incredible contaminated land). Retrieved: http://www.diena.Iv. Access: 04.04.2015.

6. Grīne, I. (2009). Lauku iedzīvotāju un apdzīvojuma telpiskās struktūras izmainas pēc Otrā pasaules kara (Cēsu rajona teritorijas). Promocijas darba kopsavilkums (Changes in the structure of rural population and spatial pattern of settlements after the World War II (Territories of Cēsis District). Summary of the Doctoral Thesis.)). Rīga: LU, 80 p.

7. Grīne, I., Beneža, S. (2016). Zvārdes pagasts šodien - iedzīvotāji, apdzīvojums, saimnieciskā darbība (Zvarde Parish today - inhabitants, settlement, economic activity).

Retrieved: https://www.geo.lu.Iv/fileadmin/user_upload/lu_portal/projekti/gzzf/Konferences/LU_74_zin_kon ference_A5_F.pdf. Access: 29.01.2018.

8. Grīne, I., Strautnieks I., Beneža, S. (unpublished). The reflection in the landscape of changes in land use and settlement within the former Zvārde bombing range (Latvia). PECSRL 25th Session. Reflection on landscape change: the European perspective. Papers of presentation.

9. Jermaks (2012). Viensētu stāsti: Aitas pelnnai, pukses skaistumam (Stories of farmsteads: sheep for profit; flowers for beauty).

Retrieved: http://la.Iv/index.php?option=com_content\&view=article\&id=338706\&Itemid=93.

Access: 14.01.2013.

10. Lakovskis, P., Benga, E., Mikelsone, Z. (2013). Platību maksājumu nozīme lauksaimniecības zemes izmantošanā (Importance of area payments for the agricultural land use). Zinātniski praktiskā konference Lauksaimniecības zinātne veiksmīgai saimniekošanai. Jelgava, LLU, 98-104.Ipp.

Retrieved: http://llufb.Ilu.Iv/conference/Latvia_Agricult_Science_Successful_Farming/Latvia_Agricult_Scienc e_Successful_Farming-98-104.pdf. Access:02.01.2018.

11. Latvijas lauku telpas attīstība un tās iespējamie nākotnes scenāriji (Development of Latvian Rural Space and its Future Scenarios) (2012). Retrieved: http://www.laukutikls.Iv/latvijas-lauku-telpas-attistibas-un-tasiespejamie-nakotnes-scenariji. Access: 20.12.2017.

12. Latvijas Republikas Ministru Padomes lēmums Nr. 329 „Par Saldus un Dobeles rajonā izvietotā aviācijas poligona likvidēšanu" (Decision of the Council of Ministers of the Republic of Latvia Nr. 329 "About the closing of air force bombing range in Saldus and Dobele Districts", 12.08.1992.

Retrieved: https://likumi.Iv/doc.php?id=66478. Access: 30.01.2018.

13. Lāce, D. (2017). Zvārde gadsimtu griežos. Fakti un atminu stāsti par Zvārdes pagastu (Zvārde in centuries. Facts and memory about Zvārde Parish). Biedrība Vienoti Zvārdei, $697 \mathrm{p}$.

14. Melluma, A. (2010). Ieskats Latvijas ainavu klājumā (Overview of the Latvian landscape). Grām. Latvijas Avīzes gadagrāmata 2011. Rīga: Izdevn. LZ, pp. 242-253

15. Melluma, A. (2012). Historical contexts and development paths of Latvian landscapes. In: Proceedings of the Latvian Academy of Sciences. A: Humanities and Social Sciences, Proceedings if the $24^{\text {th }}$ session of PECSRL: Living in landscapes: knowledge, practice, imagination, Vol. 66 (2012), Nr. 3. Rīga: LZA, pp. 2741.

16. Military heritage. Retrieved: http://www.celotajs.Iv/cont/wrth/military_lv.html. Access: 21.03.2013.

17. Nikodemus, O., Bell ,S., Grīne, I., Liepinš, I. (2005). The impact of economic, social and political factors on the landscape structure of the Vidzeme Uplands in Latvia. Retrieved: https://www.sciencedirect.com/science/article/pii/S016920460300210X. Access: 08.02.2018.

18. Ozola, I. (2015). Zvārdē neitralizē desmitiem sprādzienbīstamu lādinu (In Zvārde is neutralizing dozens of explosive charges). Retrieved: http://www.Ism.Iv/raksts/zinas/latvija/zvarde-neitralize-desmitiemspradzienbistamu-ladinu.a130588/. Access: 20.12.2017.

19. Penēze, Z. (2009). Latvijas lauku ainavas izmainas 20.un 21.gadsimtā: cēloni, procesi un tendences. Promocijas darbs (Changes in rural landscape in Latvia in 20.and 21.centuries: causes, processes and trends. Summary of the Doctoral Thesis.). Rīga: LU, 255 p.

20. Roca, M., Roca, Z., Oliveira, J. (2011). Features and Impact of second homes expansion: the case of the Oeste Region, Portugal.

Retrieved: https://pdfs.semanticscholar.org/052a/314fdd42d35014d5ca4ca94ac26bc6bfbe48.pdf Access: 20.12.2017.

21. Ruskule, A. (2013). Lauksaimniecības zemju aizaugšanas ainavu ekoloǵiskie un sociālie aspekti. Promocijas darba kopsavilkums (Ecological and social aspects of agricultural land overgrowing. Summary of the Doctoral Thesis.). Retrieved: https://dspace.lu.Iv/dspace/bitstream/handle/7/5179/30050Anda_Ruskule_2013.pdf?sequence=1\&isAllowed=y. Access: 04.02.2018.

22. Saldus novada teritorijas plānojums 2013.-2025.gadam (Territorial planning of Saldus county, 2013-2025) (2012-2013). Retrieved: https://www.saldus.Iv/pasvaldiba/dokumenti12/planosanasdokumenti9/teritorijas-planojums1/. Access: 04.02.2018.

23. Sprūde, V. (2011). 1951.gada 29.septembris. Latvijas Avīze, 29.09.2011. Retrieved: http://la.Iv/index.php?option=com_content\&view=article\&id=328517\&Itemid=177, last accessed 28 January 2013. Access: 04.02.2018.

24. Svetoka S, 2012. Zvārdes poligonā atklās stendu par sprādzienbīstamu priekšmetu apdraudējumu (In the former Zvārde bombing range will be open a information board about danger of unexploded ordnance). Retrieved: http://www.Ivportals.Iv/visi/preses-relizes/251653-zvardes-poligona-atklas-stendu-parspradzienbistamu-prieksmetu-apdraudejumu/. Access: 10.03.2015.

25. Štāls, A. (1996). Zvārdes sūrā atjaunošanās (Hard restoration of Zvārde). Diena, 14.08.1996., 7.Ipp.

26. The Zvarde base. Retrieved: http://www.celotajs.Iv/lv/e/zvardespoligons. Access: 24.01.2013. 
27. Tooma, A. (2004). Zvārde - melni nāvīgais Kurzemes katla dibens (Zvārde - 'Courland Pocket'). Žurnāls "Vides Vēstis", Nr. 4 (69), 2004.

28. Upmalis, I., Tilgass, Ē., Dinevičs, J., Gorbunovs, A. Latvija - PSRS karabāze. 1939-1998.: materiāli un dokumenti par Padomju armijas atrašanos Latvijā un tās izvešanu (Latvia - military base of USSR. 19391998: materials and documents of Soviet Army in Latvia and its disposal). Rīga: Zelta grauds, 359 p.

29. Vanwambeke S., Meyfroidt P., Nikodemus O., 2012. From USSR to EU: 20 years of rural landscape changes in Vidzeme, Latvia. Retrieved: https://www.deepdyve.com/Ip/elsevier/from-ussr-to-eu-20-years-of-rurallandscape-changes-in-vidzeme-latvia-h8cugohkFA. Access: 03.02.2018.

30. Virbicka, I. (1993). Dažreiz izzūd pat veseli pagasti (Sometimes dissapeare whole parishes). Lauku Dzīve, Nr.6.

31. Zvārdes pagasts (Zvarde Parish) (2002). Latvijas pagasti. Enciklopēdija. 2.sējums. (Parishes of Latvia. Encyclopaedia. Volume 2). Rīga: Preses nams, 685-688.Ipp. 